\title{
THE CONSTRUCTION OF MALAY CIVILISATION THROUGH MALAY PAINTINGS
}

\author{
Junaidi $^{1 *} \&$ Budianto Hamuddin ${ }^{2}$ \\ *First Author \\ ${ }^{1}$ Deparment of English Literature, Faculty of Humanities, \\ Universitas Lancang Kuning, Indonesia \\ ${ }^{2}$ Department of English Language Education, Faculty of Education, \\ Universitas Lancang Kuning, Indonesia \\ (junaidi@unilak.ac.id, budihamuddin@gmail.com) \\ Doi: https://doi.org/10.22452/jati.vol24no1.10
}

\begin{abstract}
This article aims to describe the construction of the Malay-river-civilisation as reflected in 21 paintings painted by Riau Malay artists. In-depth analysis was carried out using a semiotic approach to reveal the ideas and interpretation informing the images. The analysis focuses on the principal signs, images, and symbols presented in these 21 paintings. The findings reveal that the ideas of the Malay-river are strongly related to past and present civilizational understandings. The image of the river had a presence for the Malays, and it was established in four main categories of how artists presented their paintings, namely via: myth, the spirit of life, theiden tity of Islam, and the dark side of modern civilisation. This study suggests the message promoted through these images communicates to their audience that, beyond the beauty of the Malay cultural identity, nature, and civilisation, there are challenges relating to marginalisation, environmental destruction, and corruption.
\end{abstract}

Keywords: river, Malay, civilisation, painting, semiotic

\section{Introduction}

The term Melayu, Malayu, or Malay, is very ancient, it is a term used to define the state of being Malay or of distinguishing Malay characteristics, and is also used to refer to personifying that which binds the Malay people and forms the basis of their identity and unity. Malays seem united by a notional shared identity albeit somehow divided by divergent histories, political boundaries, and the peculiarities of local experience and variant dialects (Barnard, 2004). People who 
call themselves Malay can be found in many countries in Southeast Asia, or specific people who reside in Sumatra or the Straits of Melaka region. Although the term 'Malay' is widely used and readily understood in this region, it remains open to varying interpretations due to its varied and fluid characteristics. 'Malay', as an identity, or nationality, is considered as one of the most challenging and perplexing concepts in themulti-ethnic world of Southeast Asia (Barnard \& Maier, 2004). However, in this study, the term Malay refers to Riau Malay in Sumatra, Indonesia

Riau Malay, as one of the sub-ethnicities of Malay, has a rich cultural background; its culinary, crafts, and arts, such as dance and paintings are already well-known around the region (Al Azhar, 1997). This heritage has been passed down for generations, especially performing arts, such as traditional dance or active art scenes, such as paintings. Riau is one of the most developed and active art scenes in Sumatra or even in the straits of Melaka itself. It is home to some of themost exciting and interesting local artists who have developed and maintain ed their body of work regionally and globally.

Furthermore, many artists believe that a work of art should, especially a painting, contain a message, explicitly or implicitly, through the way the artists draw thelines (Bourdieu, 1968). All artists, including local Riau Malay artists, may produce images that reflect the way they view the world. This can be seen in the way they draw the painting surface, the selection of objects, and the painting format. The steadiness of their hand when organising the elements - principle signs, images and symbols, including themes - they choose to represent, reflects the way they view the world (Schapiro, 1937). The basic structure of a painting is somehow constructed by lines that sometimes are not visible or might symbolise, as this study tries to underline, that there is a certain resemblance between pictorial image making and the creation of written language that contains a meaning or message (Bal \& Bryson, 1991; Goodman, 1968; Becker, 1989). Therefore, as indicated above, these studies believe that all painters, including Malay artists, work in a pictorial language by following the set of standards, or basics and rules of picture making that contain a message. Moreover, to understand the study of works of art, signs and symbols, either individually or grouped in sign systems, semiotics can give us more insight into the work source and meaning (Van Leeuwen, 2001). The next section explains how the semiotic point of view helps in analysing the basic rhythm of the paintings and understanding behind the visibledetails, i.e., principle signs, images, and symbols. 


\section{Literature Review}

This section presents an overview of some literature to help and understand this present study and establish its significance. The overview is based on past and contemporary studies that scrutinised the various points of view of semiotics in examining the nature of the river, civilisation, and Malay people through selected paintings. From the semiotic point of view, the passion of the present study is in observing the principal signs, images, and symbols presented in the paintings.

\section{Painting, Artist, and Riau Malay Society}

Art is always about society and artists who have always been part of the culture; art has never been independent or absolute (Paul, 1981). The arts have a particular context or community referral. Artwork, such as a painting, will not be free from any form of assessment. It lies in what forms are required by the society of the production of artworks by the artist. It is undoubtedly the knowledge that can shape the development of thinking. Knowledge of art is somehow able to penetrate other zones to shape an intellectual community (Kelly, 1985; Helguera, 2011). Further, art is a reflection to construct the state of consciousness and how the audience views it and how it develops into a new experience. In other words, the role of artwork, such as a painting, is to give "voice" by interpretation in the context of the appropriate theory, where the final product can be seen to reveal their stories, i.e., the whole body of knowledge (Charman \& Ross, 2006).

In Riau Malay art, knowledge seems to try to reach the boundary of the other fields to foster interaction within the community and artists. As a result, nowadays, many artworks from local Riau Malay artists reflect interdisciplinary ideas that are geared to the needs of society (Al Azhar, 1997). Riau is one of 33 provinces in Indonesia. The most populous ethnic group living in the province is the Malay (Al Azhar, 1997). The Malay people living in the area have relied on the four major rivers from a long time ago. Therefore, the river has a strong relationship with the past and present history of civilisations. Further, for Riau Malays, the rivers are not only used for trade routes or fishing activities but, somehow, the river is the life of the Malay (Dahlan, 2015; Hamidy, 2011). Therefore, finding the elements of the river in Riau Malay artworks, such as a painting, is a common thing. The relationship between the Malay people and rivers is not simply one of physical contact but also in terms of social and cultural values, including the perception of the world and religion (Klaver, 2012; Thornton, 2012; Lun 2012; Drew, 2012; Gracia, 2012; Hiwasaki, 2012). In Malay society tradition, water (river and sea) is frequently used to present pureness, state of feeling, brotherhood, and life (Zulkeflie Hj. Ayob \& Zainuddin Md. Nor, 2012). 
Due to the very significant role of rivers and water in the life of the Malays, some Riau painters have expressed their ideas concerning the rivers through artworks. Rivers inspirethem to produce creative works. The works of Riau Malay artists who used the concept of the river could be seen at the Painting Exhibition entitled "Per[adab]an 4 [Sungai Riau] \#2" (The Civilisation of 4 [Rivers in Riau])\# 2" at Taman Budaya (Cultural Hall) ofBali Province, 27-31 August 2017. The choice of the civilisation of the four rivers' theme confirms that rivers can represent the Malays from various perspectives, such as life, ideas, dreams, myths, culture, character, nature, economy, pain, and sorrow in civilisation.

There were 35 paintings displayed in the exhibition. The strict selection of which paintings could be displayed in that exhibition by the curators from the national museum, also became the major reason why this present study decided to explore and look for the messages beyond these paintings. In this research, only 21 paintings were selected based on its specific theme. Taking the cue from van Leeuwen (2001), that to understand a study of works of art signs and symbols, either individually or grouped in sign systems, semiotics can give us more insight into the work source and meaning. Therefore, this present study based its art interpretation on a semiotic perspective to interpret the messages contained in these 21 paintings over time. The messages reveal the identities of the Malay people in Riau regarding their rivers. Through these selected paintings, this present study also introduces the cultural perspective from one of the sub-ethnic groups of Malay who reside in Riau Province regarding their rivers and civilisation.

\section{Semiotics and art Interpretation}

Definitions of semiotics can be easily found on the internet or as used by many academics from different disciplines, e.g., social sciences, linguistics, arts or humanities. However, many of these scholars seem to agree that semiotics can be seen as a study that focuses on art signs and symbols that are intended to give us more insight into the work source and meaning interpretations, therefore, this places semiotics as a specialised discipline in interpreting "signs and symbols" (Unsworth, 2008; Hodge, 2014; Augustyn, 2001; Norris, 2013; Brejcha \& Marcus, 2013).

Moreover, how semiotics displays such an interpretation in the broad sense (language, images, objects, signs, and symbols) appears to be a broader theme than the study of symbolism itself. This present study contends that semiotics can offer a useful perspective for understanding formalism and acknowledging the variable relationship as well as in providing a dynamic understanding of the images, objects or other factors, such as culture and society. 
Different media, such as pictures or paintings, carry different meanings despite the message content. This meaning and messagecan be seen as visual signs that look for the possibility of a language that already exists and is used or can be interpreted by people's consciousness and convention. This linguistic sign consists of content like sense and meaning of expression like in a painting. Further more, it becomes a translation from linguistic to visual expression, and the forms are as random as in linguistic signs. As Bal and Bryson (1991) mentioned: "Most paintings have a double meaning; visual and symbolic, conventional and arbitrary". So, this form of anchorage of meaning opens the gate of this present study analysis up to not only one, but several meanings or messages without unsettling the central indented meaning. Finally, this study forces its analytical mind to interpret the painting both complexly and accurately.

\section{Methodology}

The idea of representation by chance, where things do not follow the rules but are used as signs has, however, been widely explored in the visual arts, such as painting (Unsworth, 2008). Semiotics is often concerned with the study and analysis of pictures to provide a more understandable verbal description while maintaining confidence in the objectivity of the practice (Sonesson, 1994). Moreover, Hodge (2014), Augustyn (2001), Norris (2013), and Brejcha and Marcus (2013) appear to concur that semiotics on visual art could translate an image or a picture or painting as an artwork into words, and this is where this study sees the principles of semiotics on visual art come in to use as they function to map out and decode as a discipline. Therefore, the semiotic approach on visual arts, focusing on them in the paintings was carried out to explore the ideas beyond hem and to take a stance on understanding why the major theme is named the Malay-RiverCivilisation construction.

The stances in this present study only employ the semiotic approach in observing and interpreting the part of the principal signs, images, and symbols presented in the paintings, then they are explained descriptively, which this study believes to be the classical association for artists to determine the difference between the signifiers and the signified (Chandler, 2017). Nevertheless, this study aims to describe the Malay-River construction in 21 selected paintings by Riau artists over time. The national library curator carefully selected these paintings and presented them at several Indonesian art exhibitions under the major theme, Malay-River-Civilisation construction. This study hopes the results of its interpretation will help everybody to clearly see the ideas beyond the paintings and become acquainted with Malay history, customs, and traditions. 


\section{Findings and Discussion}

An analysis of the 21 paintings revealed that the Malay-River-Civilisation constructed and found exists in the painting through various aspects, such as myth, culture, the dark side of modern civilisation, the spirit of life, and Islam as an identity of the Malay people.

\section{Malay-River and Myth}

The construction of the Malay-river deals with myth and culture. Like other ethnic groups, the Malay also have myths and cultures integrated into their life. The myths of the rivers and pattern s of Malay culture are found in several paintings: The Malay-River-Myth in this painting is constructed through theimages of the dragon of Siak River, a young lady, and the river (Figure 1). The principle sign of this painting is the anger of the dragon to the young lady. The painting captures a dragon that looks very angry. It opens its mouth wide and shows its tongue, teeth, and red eyes.

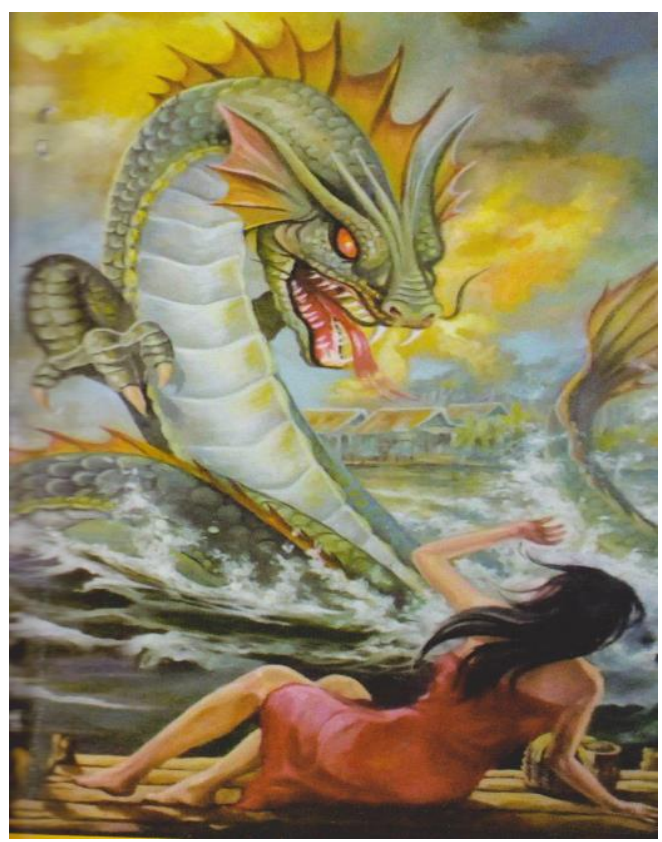

Figure 1: Oil painting "Mitos Sungai Siak (the myth of Siak River) on canvas 100 cm length x $60 \mathrm{~cm}$ width painted by Refnaldi (Collection of Dinas Kebudayaan Provinsi Riau)

Thedragon illustrated wants to prey on thelady who is bathing or washing clothes in the river. In Malay life, myths are part of social life, and are not judged by the 
true or false content of themyth, but from thelesson gained. The lesson or message in this painting is that the giant dragon that resides in the Siak River is depicted as being angry with the young girl. In the Malay myth, it is believed that the dragon of the Siak River may appear at any time to swallow its prey if somebody breaks the rules or does something that is forbidden. It seems that the dragon may have appeared when it saw that this young lady had broken the rules by wearing an inappropriate dress in terms of what young Malay girls should wear.

The next construction of the Malay-river-myth is depicted through an element of "Barondo", an ornamental boat that is full of decoration from the regency of Kuantan Singingi. This decorative boat is a tradition of the Kuantan Singingi regency that was designed to express the joy of the Malays in Kuantan Singingi in welcoming the Idul Fitri (Eid) festive season or other big events, e.g., boat races. The barondo is used by the Malays to express their gratitude to God for all His blessings to them and "to gain more blessed years ahead". The Barondo boat painting also illustrates the strong Malay culture concerning activities on the river (Figure 2). The principle signs in this painting are the image of the man dressed in Malay costume playing a musical instrument and dancing on the barondo. This study considers this to be sending a message that the Malays are "a happy and a blessed people with their rich culture". However, nowadays, the barondo activities are quite difficult to enjoy due to their rarity due to the lack of support from the local government for the events. This might be the reason why the painter came out with the idea of cultural preservation through Barondo.

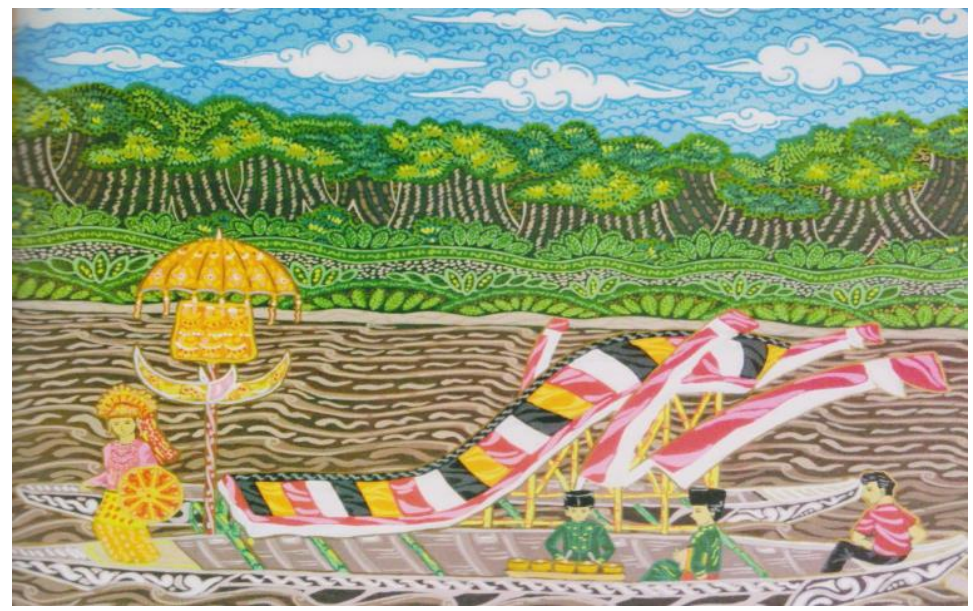

Figure 2: Acrylic painting "Barondo" on canvas $100 \mathrm{~cm}$ Length $\times 80 \mathrm{~cm}$ Width painted by Yelmi Nanda Resfi (Collection of Dinas Kebudayaan Provinsi Riau) 
Moreover, the rapid modernisation seems to have developed thoughts, lifestyles, as well as social implications that encourage the community to become acquainted with modern facilities. It means people have begun to abandon old things, including types of transportation that are no longer considered appropriate or as being less efficient. The old transportation facilities, i.e., barondo boat, have begun to be abandoned by the Malay people and replaced with modern river transportation. This has made it quite difficult to find barondo boats and events anymore in Riau, they only exist in Kuantan Singingi regency. They have slowly begun to disappear from the Riau Malay Culture. Therefore, through this painting, the artist tries to create a nostalgic moment with thehope of preserving the cultural heritage.

The construction of the Malay-river-myth is also marked by a painting entitled "Bono". Bono is a typical long wave that runs along the Kampar river and shows two surfers on the Bono wave (Figure 3). The principle signs of this painting establish how humans are trying to play with the wave (nature). This wave can only be found in the Kampar river estuary. It is one of the wonderful natural phenomena found in the Kampar River. This great wave comes at certain times due to the Kampar river encountering the sea currents leading upstream and downstream.

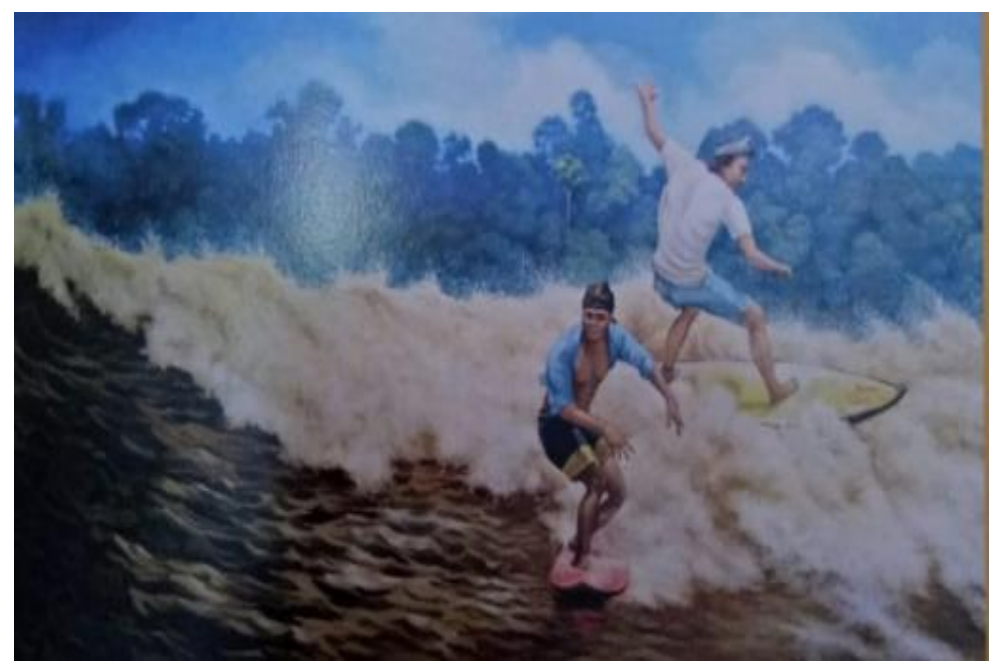

Figure 3: Oil painting "Bono" on canvas $140 \mathrm{~cm}$ length $x 80 \mathrm{~cm}$ width painted by Indra Maiyeldi (Collection of Dinas Kebudayaan Provinsi Riau)

This painting concerns the myth of the mystical powers that generate the wave. Although it is not shown clearly in this painting, this painting tries to tell it through 
the selection of the wave colours, i.e., black, brown, and white. These colours come with a message for those who want to play with thebono. Moreover, the images in this painting depict the exotic nature of the Malay meaning "do not be afraid too much, please enjoy the bono but be careful".

The construction of the Malay-river-myth is depicted in the painting entitled "Tanjak Tebing Runtuh" (Figure 4). Tanjak Tebing Runtuh is a traditional Malay headdress. Tanjak is a kind of headdress that wraps around thehead. The idea is that this traditional headdress comes from the broken cliff near the river because of the erosion of the river banks in thepast. Thereare many types of tanjak, each of which contains a philosophy. The more complex its shape means the higher the position of those who wear it. Tanjak are usually used by a male figure in Malay society, and symbolises a social class or authority.

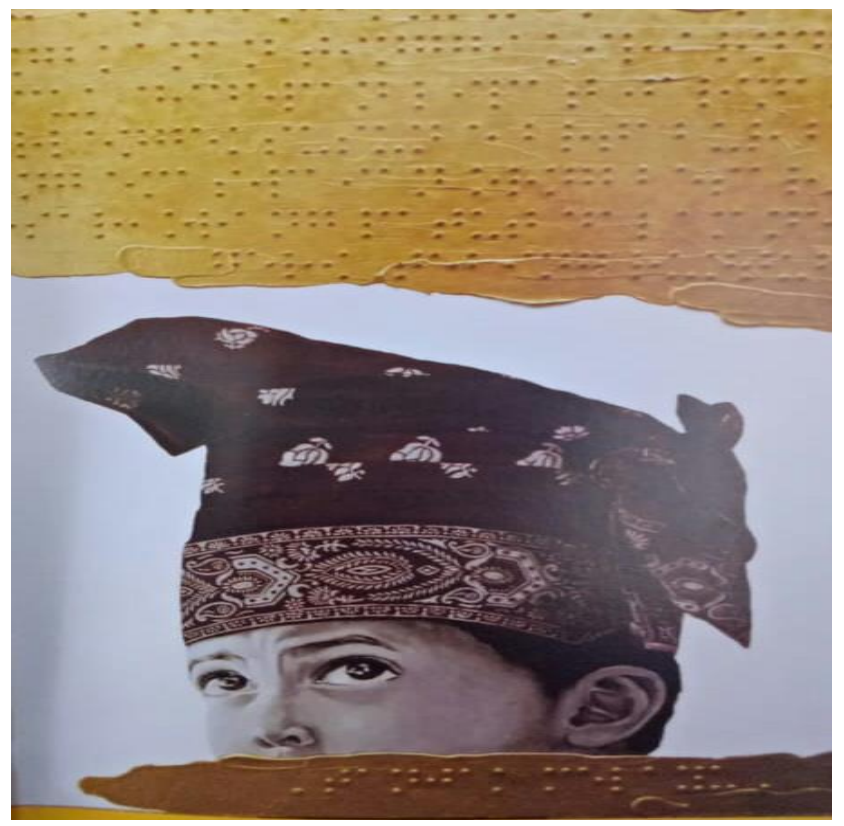

Figure 4: Acrylic painting "Tanjak Tebing Runtuh" (The Broken cliff Headdress Shape) on canvas $120 \mathrm{~cm}$ length $x 80 \mathrm{~cm}$ width painted by Habi Maulana (Collection of Dinas Kebudayaan Provinsi Riau)

Theimage of the tanjak and a young man looking up arethe principle signs in this painting. The ideas behind these principle signs seem strongly related to the young man, authority, and looking up, i.e., further, beyond. It tries to tell its audience that the authority should be in the hands of the young man who prepared himself to see further and beyond. Moreover, an interesting image is also found on the top and bottom of the painting in that there are braille alphabets 
explaining the title of the painting and traditional proverbs expressing the philosophy of the collapsed cliff headdress. The presence of theimage of thebraille alphabets in this painting also provides an opportunity for theblind to understand the meaning of the painting. It means that the painting's symbol is "for everyone", or that this young Malay leader is for everyone in the future.

\section{Malay - River, and Spirit of Life}

A river is an integral part of the Malay life. Since the river is hope for the Malay people, the Malays have a spirit of life. The painting entitled "Destination" (Figure 5) depicts the construction of the Malay-river, and the spirit of life through the images of the mud on the river banks, human footprints, and kerosene lamps. These images have a symbolic meaning that needs to be understood. The mud in this painting might represent the merging of water and earth (Malay land). The footprints suggest local knowledge, or the dreams or hopes of the Malay ancestors, and the petromax lamps can be interpreted as enlightenment for the Malay people.

The analysis of this study considers the principle sign in this painting as being the "kerosene lamp without the light", which is trying to send the message "light on the ancestors' dreams and hope through the local knowledge," and you will achieve a better life as your "destination".

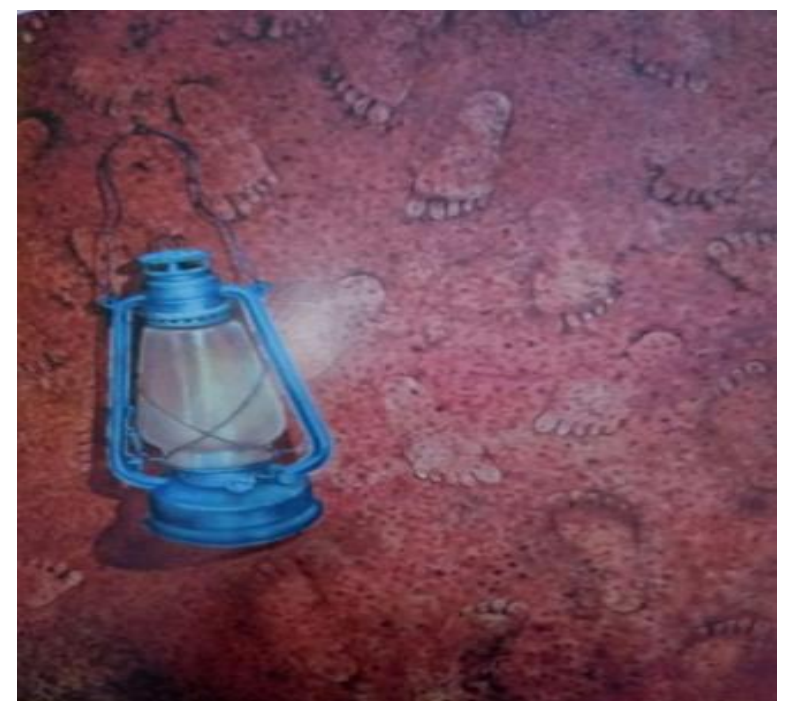

Figure 5: Acrylic painting "Destination" on canvas $130 \mathrm{~cm}$ length $x 150 \mathrm{~cm}$ width painted by Kodri Johan

(Collection of Dinas Kebudayaan Provinsi Riau)

The painting entitled "Berlabuh di Dermaga" (Figure 6) depicts the construction of the Malay-river-spirit of life through the images of the port, the dock, and a 
porter who is picking up goods. The principle signs depicted in the painting are the image of the porter and the ships in the dock. Porters picking up goods are commonly found at any port alongside rivers. It provides an image of somebody who is poor but has strength, and that the ships are the sea transportation model that brings the resources in huge quantities. This painting portrays the dock as an important rolein Malay economic activity with many ships anchored there. It tries to depict that the development of cities on Malay land started from the ports along the rivers. However, the Malay people are on the weakest side of the dock. From the principle signs, it seems that the images in the painting symbolise that "The strength of the Malays still exists even though they are not lucky enough in their homeland."

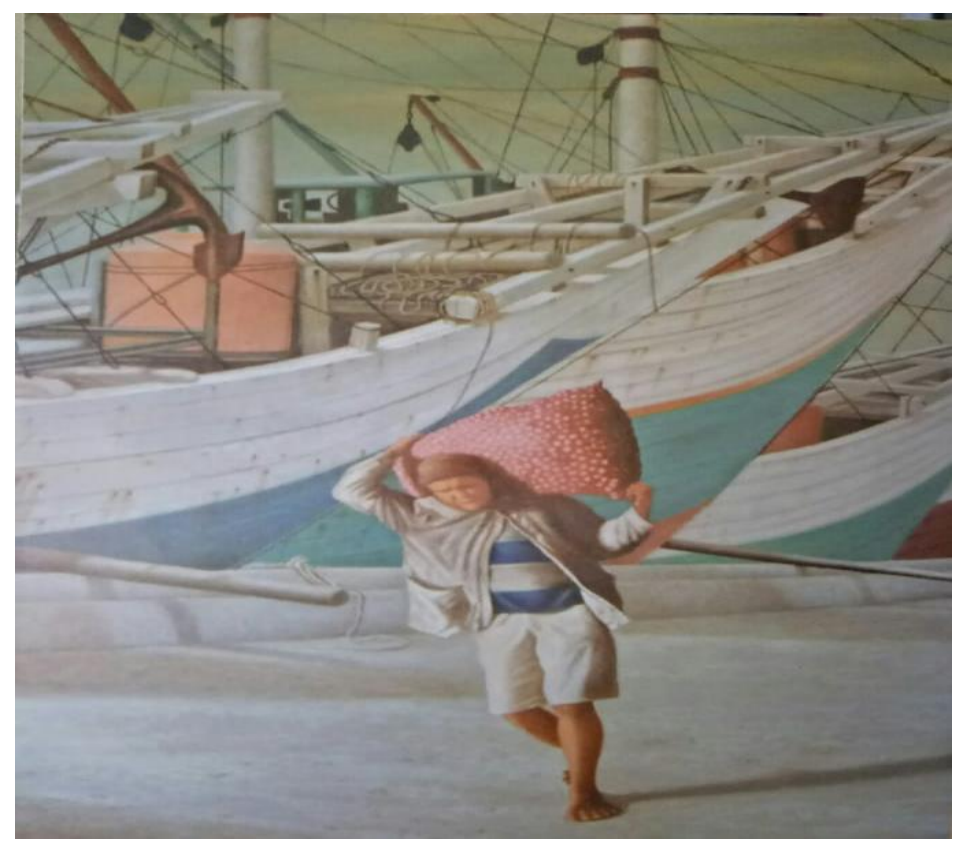

Figure 6: Oil painting "Berlabuh di Dermaga" (Anchored on the Dock) on canvas $100 \mathrm{~cm}$ length $\times 138 \mathrm{~cm}$ width painted by Rusli (Collection of Dinas Kebudayaan Provinsi Riau)

The painting entitled "Penantian I" (Waiting I) (Figure 7) constructs the Malay-river-spirit of life through the images of the river, boat, and its multicolour splashes. The title, "Penantian I" (Waiting I), seems to depict waiting for "hope." Theimage of theriver and boat are the principle signs in the painting. It can depict hope for humans and nature. In the Malay context, rivers and boats are part of human life to meet their needs in nature. The potential and various resources of a 
river can be made use of by the Malays. The boat in the painting can be seen as a transportation object explicitly and as an effort implicitly by the Malays to pick up their hope. Waiting can be implicitly interpreted in this painting as not being a useless wait, but waiting for hope and that the hope itself should be picked up through effort. The "I" character in the title means that the Malays will continue to struggle to pick up their hope. Nevertheless, the splashes of multicolour in this painting give the impression of the sense of effort, that the waiting is more challenging and complex and not effortless. However, the selection of these multicolour splashes in bright context seems an attempt to send the message that the Malay people will live in harmony and that they are optimistic and have an excellent attitude in picking up their hope.

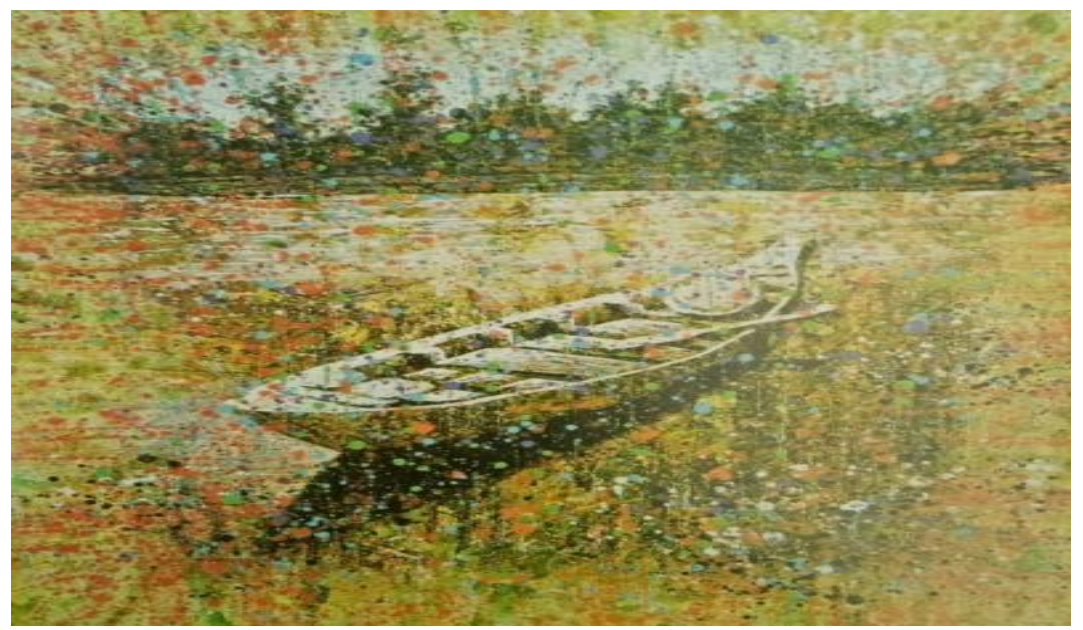

Figure 7: Acrylic painting "Penantian I" (Waiting I) on canvas $60 \mathrm{~cm}$ Length $x 50$ cm Width painted by Alza Adrison (Collection of Dinas Kebudayaan Provinsi Riau)

The painting entitled "Memancing" (Fishing) (Figure 8) constructs the Malayriver-spirit of life through the images of water, various kinds of fish, and fishing hooks. The existence of the principle signs here features in the fishing activities of the Malay. It depicts the empty hooks on the water. This study sees thehooks here as symbolising the effort and firmness of the Malay people. The Malays are very resolute in facing their life. Malays believe that firmness does not come on its own, it needs effort to obtain it. God has provided fish (prosperity) in the river, and people have to exert effort to get it. The sharpness of the fishing hook also symbolises a need to focus on the consistencies in life. 


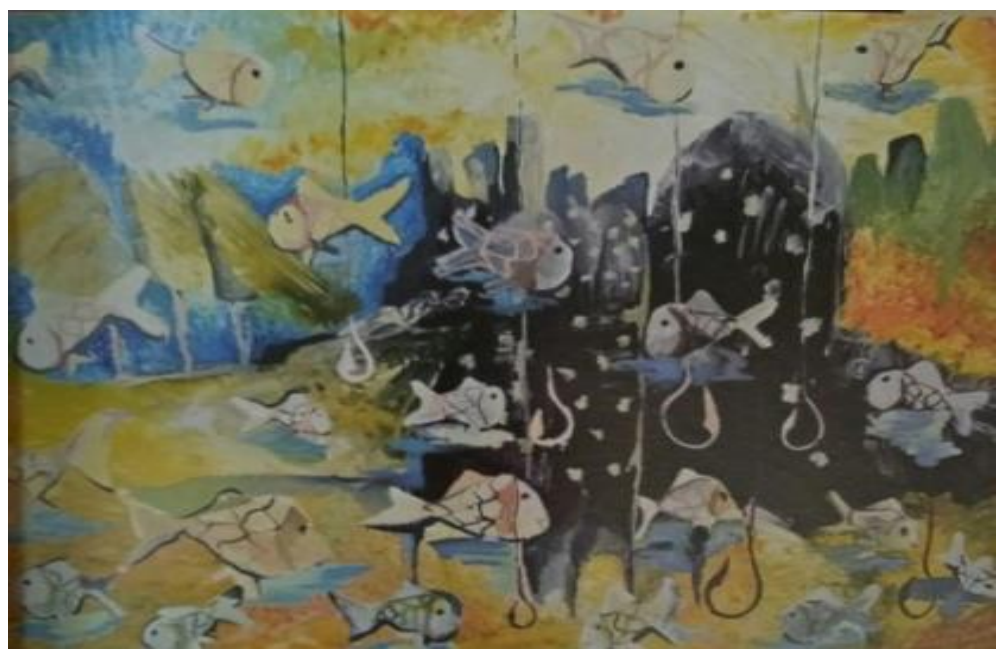

Figure 8: Acrylic painting "Memancing" (fishing) on canvas $150 \mathrm{~cm}$ length $x 100 \mathrm{~cm}$ width painted by Debby Nurianto

\section{(Collection of Dinas Kebudayaan Provinsi Riau)}

The painting entitled "Aktivitas di Sungai Siak" (Activities by the Siak River) (Figure 9) constructs the Malay-river-spirit of life in the images of the river, transportation boats, cargo ship, houses near the banks, and the Siak bridge. The principle sign in this painting is the activities in the river (Siak). The analysis of this study in this painting is that these images are closely related to the daily activities in the Siak River.

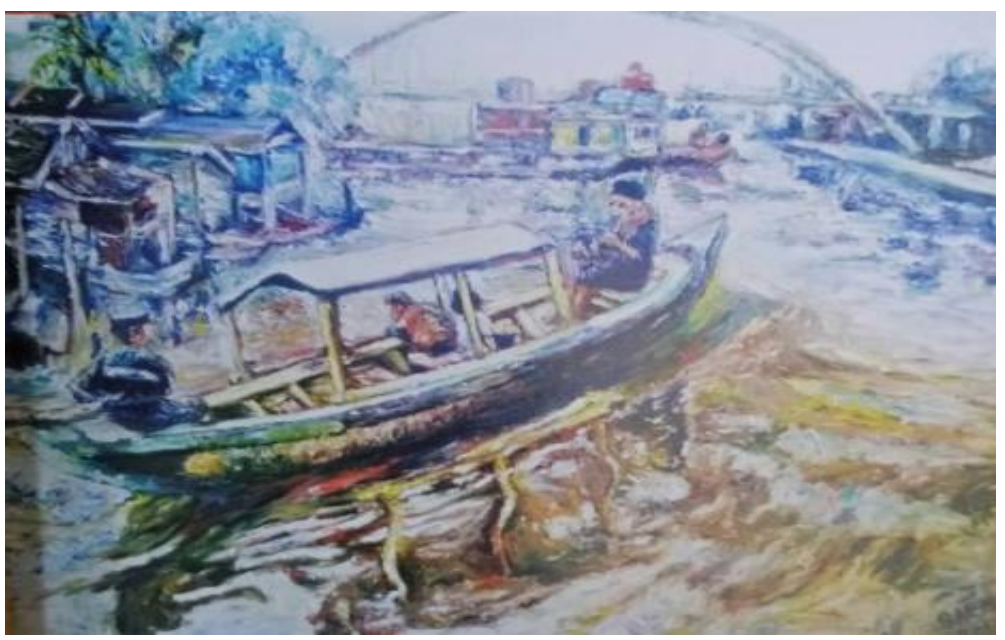

Figure 9: Oil painting "Aktivitas di Sungai Siak" (Activities by the Siak River) on canvas $80 \mathrm{~cm}$ length $x 120 \mathrm{~cm}$ width painted by Ibrahim) (Collection of Dinas Kebudayaan Provinsi Riau) 
Moreover, the presence of the bridge depicts that civilisation in the Malay country is maintained. Although bridges arereadily available to cross and connect areas of Senapelan and Rumbai, boats are still used as a means of transportation to cross the river. This means that the interaction of "both modern and traditional life can be found here." The social interaction takes place side by side with modern and traditional support.

The painting entitled "Ayam-Ayam Tepian Sungai" (Chickens by the River) (Figure 10) constructs the Malay-river-spirit of life through the images of the river, boat, fisherman, and chickens. The chickens here are the images that are the focus of this painting. Although there are seven images of chickens, the black rooster is the principle sign in the painting. The rooster, in the Malay context, can be symbolically interpreted as courage and reliability. This painting also depicts the reliability of fishermen on the banks of the river. The fishermen are reliable people. Although their life is more and more threatened by modern civilisation, they continue to struggle to survive through their courage and their reliability. Indeed, poverty makes them suffer but does not cause them to die or lose hope.

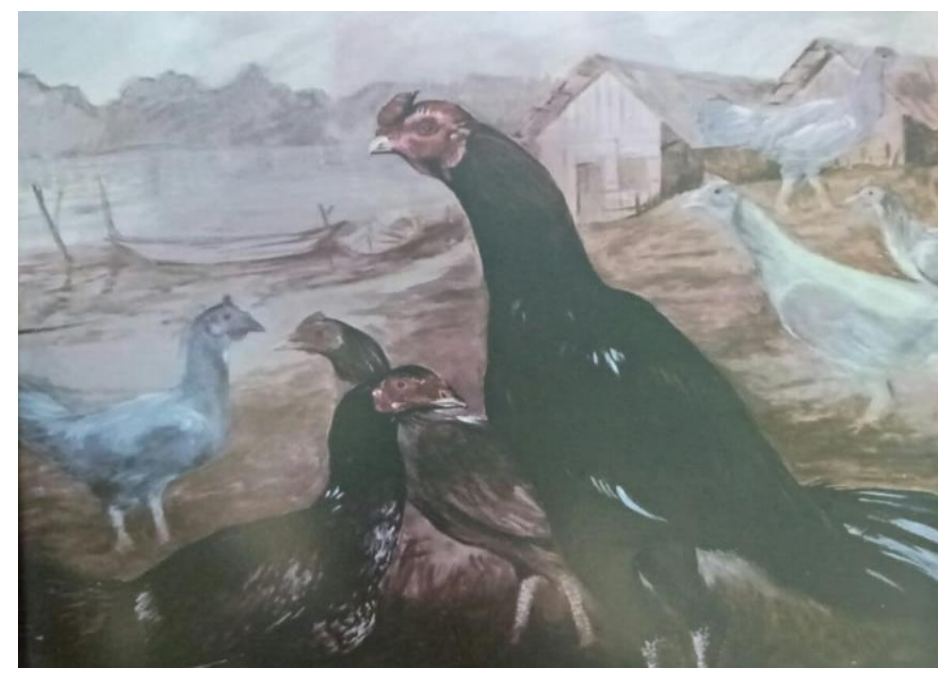

Figure 10: Acrylic painting "Ayam-Ayam Tepian Sungai" (Chickens by the River) on canvas $70 \mathrm{~cm}$ Length $x 70 \mathrm{~cm}$ width painted by Dasril (Collection of Dinas Kebudayaan Provinsi Riau)

The painting entitled "Langkau Kuala Sungai Indragiri" (Indragiri River Estuary) (Figure 11) constructs the Malay-river-spirit of life through the images of rivers, boats, and Langkau or a place to dry out coconuts. The principle sign of this painting is a langkau on the bank of the Indragiri River. This painting depicts the 
economic activity of people by the Indragiri River whose living is earned from coconuts and its derivate products. It is as if it is trying to say through the painting, "we are rich with coconuts".

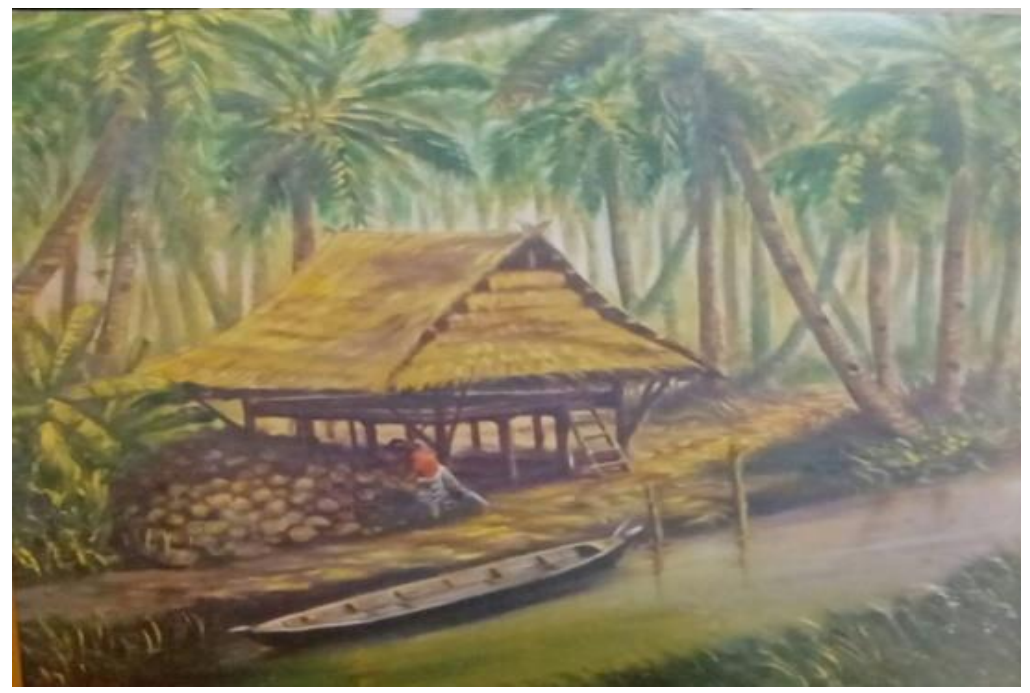

Figure 11: Oil painting "Langkau Kuala Sungai Indragiri" (Indragiri River Estuary) on canvas $90 \mathrm{~cm}$ length $x 80 \mathrm{~cm}$ width painted by Adi Lukis (Collection of Dinas Kebudayaan Provinsi Riau)

\section{Malay - River and the Identity of Islam}

The main values underlying the Malays are Islamic values. Islam was once spread along water routes and influences the social and cultural system of the Malays. That is why the Malay culture is according to the dictates of the Islamic values. The values function as basic principles of the Malays. Two paintings promoting Islam as the identity of the Malays are found. The painting entitled "Tuan Guru Pesantren" (Male Religious Teacher of Islamic Boarding School) (Figure 12) constructs the Malay-River and the identity of Islam through the images of the Male Religious Teacher of Islamic schools, as well as his accessories and the costume hewears. It strongly represents Islamic attributes and identity. Moreover, this painting shows an image of a male Islamic religious preacher named Shaykh Abdul Wahab Rokan. The word Rokan as his last name was taken from the name of the river where he used to reside. He was a great figure in Malay history and acted as a prominent Islamic scholar and advisor of Tarekat Naqsyabandiyah, which is an authenticspiritual path (tariqat) that is followed by many people in Riau until now. The term "Tuan Guru Pesantren", who spent most of his time by the river of Rokan, is the principle sign in capturing an authentic figure of an Islamic preacher in Riau. 
The existence of the image in the painting represents the existence of a strong relation between Islam and the Malay people. The preacher's image, which was selected as the centre of the attention in the painting, is intended to send a message that he has a special place in the Malay land.

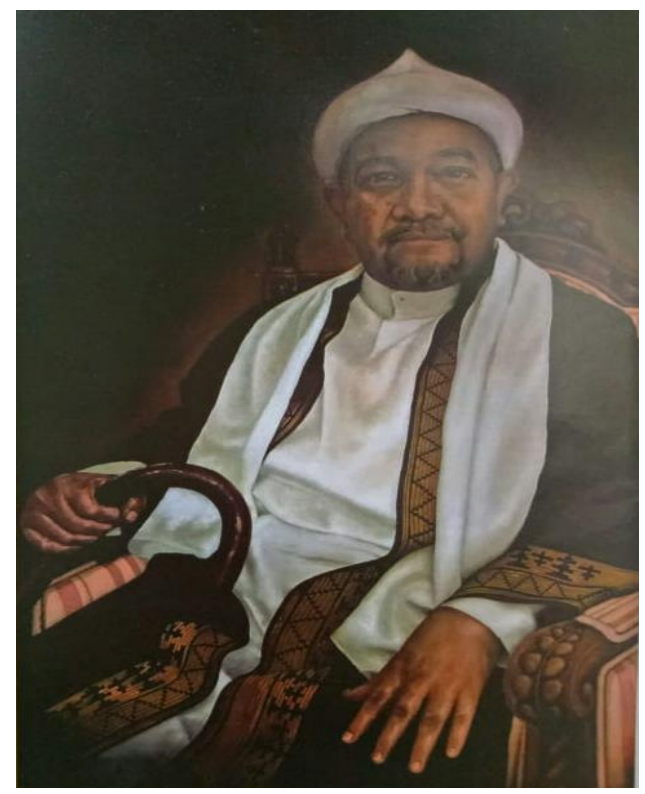

Figure 12: Oil Painting "Tuan Guru Pesantren" (Male Religious Teacher of Islamic Boarding School) on Canvas $140 \mathrm{~cm}$ Length $\times 90 \mathrm{~cm}$ Width painted by Yudi YS (Collection of Dinas Kebudayaan Provinsi Riau)

The word 'Rokan' after his name shows that it not only addresses a specific region or river in Riau, but also shows his origin and out of respect for this authentic Malay figure in relation to what he did for Islam and Riau in the past. Nevertheless, the main image presented in this painting shows the existence and the harmony of the Malays and Islam.

The painting entitled "Putri Melayu Rokan" (A girl from Rokan) (Figure 13) constructs the Malay-river-and the identity of Islam through the image of the female girl who came from Rokan river village holding the Holy Quran, as it is mentioned in the title of the painting as well as her accessories and costume she wears. It strongly represents Islamic attributes and identity. The Malay-River construction in this painting is depicted through the figure of a princess wearing baju kurung (body-hugging jersey dress) and selendang (a shawl or stole worn over one's shoulder or diagonally across the body) and holding the Holy Quran. The curtain of various colours behind the princess strengthens the Malay nuances in the painting. 


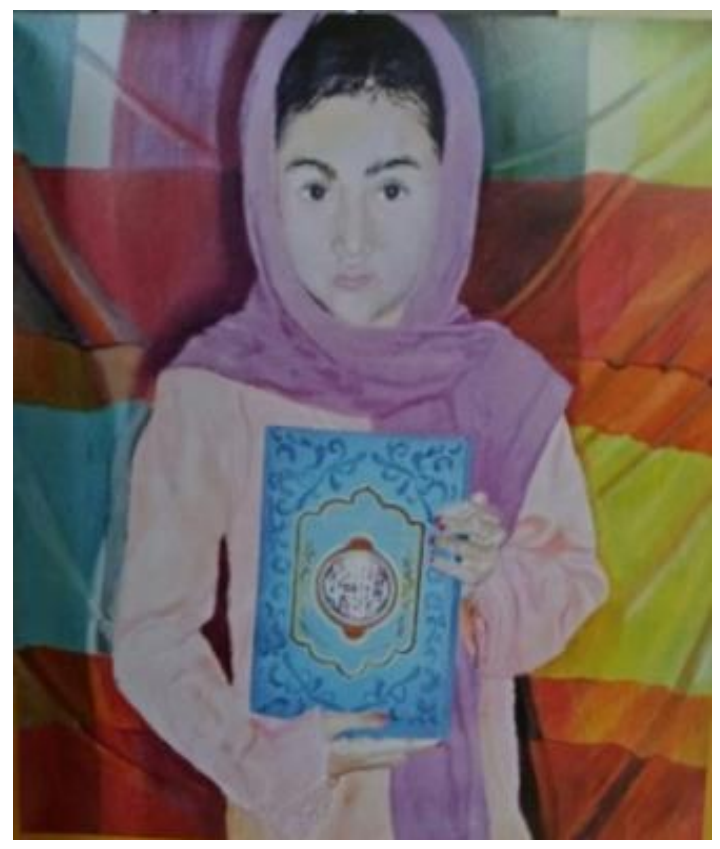

Figure 13: Oil panting "Putri Melayu Rokan" (A girl from Rokan) on canvas $80 \mathrm{~cm}$ length $\times 70 \mathrm{~cm}$ width painted by Syarif (Collection of Dinas Kebudayaan Provinsi Riau)

In line with the title of the painting entitled "Putri Melayu Rokan," the female figure represents the harmony of Islam in a Malay character who resides by the Rokan River. Moreover, most of the Rokan Malay people in the past lived along the Rokan river banks. They arewell known as a sub-Malay ethnic group and their Islamic identity. The image shown in this painting is that the Quran provides guidance for Muslims as well as in the Malay culture. Theimage of theQuran here is to show a strong idea that it is the primary guidance for any Malay teenager to follow. While the bajukurung and selendang images show strong ideas in terms of what Malay teenagers are supposed to wear.

\section{Malay-River and the Dark Side of Civilisation}

The civilisation of the four rivers in the Malay land does not always have a good impact on the life of the Malays. It is a fact that civilisation is more concerned with the economic aspects than the "civilisation" itself, which has brought suffering to the Malays, as constructed in the following paintings. The painting entitled "Jejak Tikus \#2" (Footsteps of the Rats \#2) (Figure 14) constructs the Malay-river and the dark side of civilisation through rivers, boats, rats, river products, and fishing tools. The Malay-River and the dark side of civilisation is constructed explicitly 
through the images of the rat's footsteps. The principle signs in this painting are the rat's footsteps. Rats in Malay culture symbolise a particular meaning, e.g., thieves or perpetrators of corruption. This painting shows the damage that occurred because of corruption in the Malay land. Corruptive behaviour has destroyed the Malay land and even the nation. The rats were trying to break the boat, which can be interpreted here as the nation, while the various kinds of goods scattered on the boat indicate the national resources.

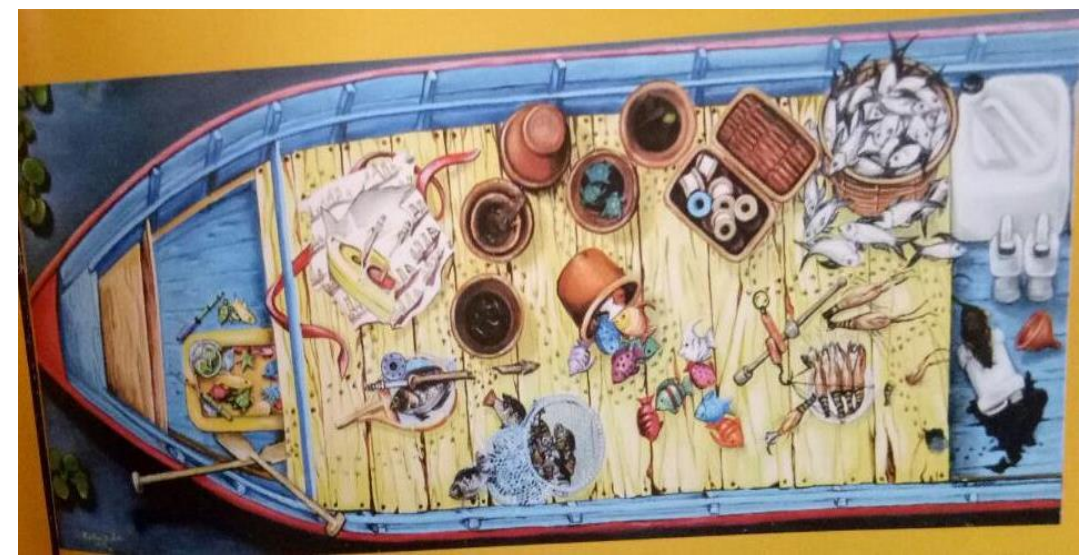

Figure 14: Oil Painting “Jejak Tikus \#2" (Footsteps of the Rats \#2) on Canvas 140 $\mathrm{cm}$ Length $\times 60 \mathrm{~cm}$ Width by Ferdian Ondira Asa) (Collection of Dinas Kebudayaan Provinsi Riau)

This painting conveys a message of social criticism against corruption in the Malay land. The river, which plays a very important role in the life of the Malays, is also damaged by corruption. Ironically, this painting tries its best to criticise corruption, which, in recent years, has become an unfortunate habit in Malay civilisation. The Malay-river construction and dark side of civilisation are also established through the rivers, boats, river products, and fishing tools. It seems that the painter tried to frame these images as being interconnected, which suggests the idea that the chaos in the river is getting stronger and is caused by the rats.

The painting entitled "Dampak" (impact) (Figure 15) constructs the Malay-River and the dark side of modern civilisation through 21 sketches of images in the paintings. These sketches depict various types of ecological damage to Malay land that will be turned in to a disaster for human beings. The analysis in this study somehow reveals an implicit message saying, "if the river and forest (nature) are sick the human and animal life will be in trouble". This message is reflected through the images, which show damage, not only to the river and the 
forest, which caused thenatural imbalance of the ecosystem in theMalay land, but also tries to send a message that "the Malay identity will perish in the end". This painting simply implies social criticism of civilisation that causes natural and social destruction.

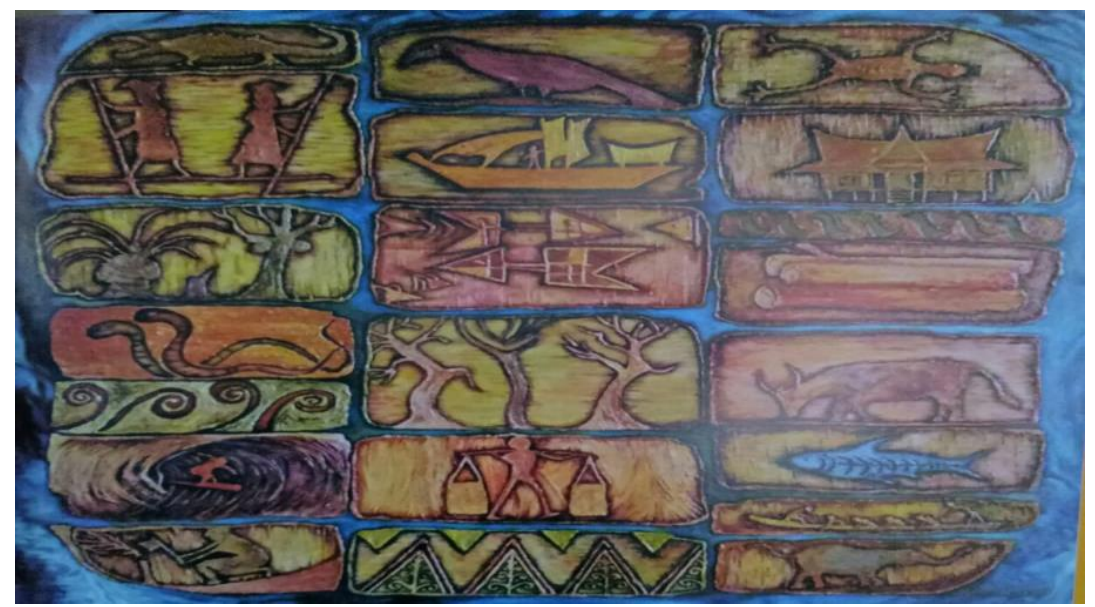

Figure 15: Acrylic Painting “Dampak" (impact) on Canvas $80 \mathrm{~cm}$ Length $x 80 \mathrm{~cm}$ Width painted by Armen Titof

(Collection of Dinas Kebudayaan Provinsi Riau)

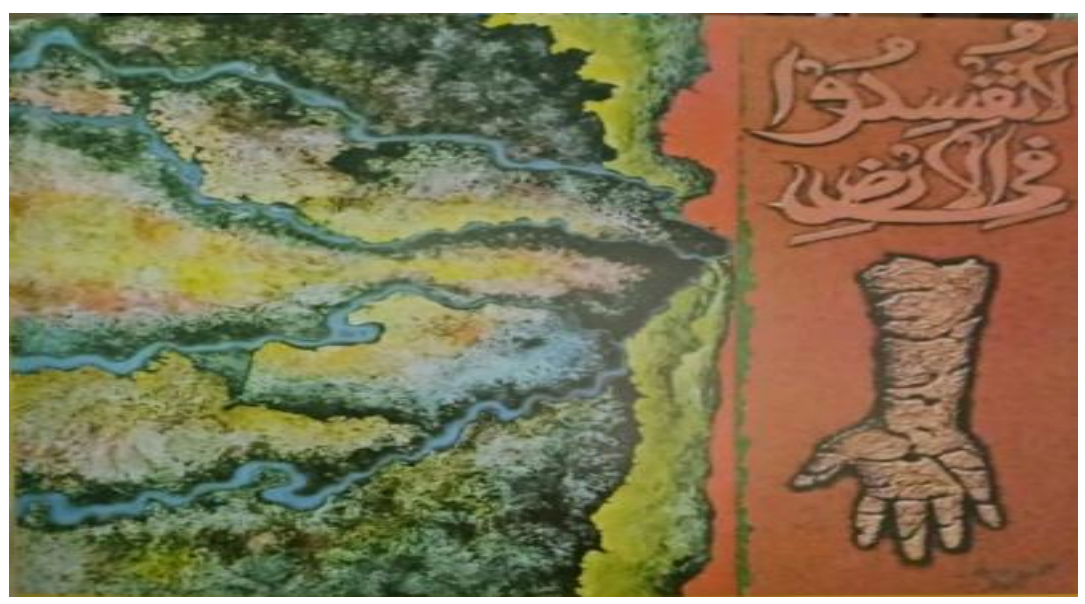

Figure 16: Acrylic painting “Ulah Tangan Manusia” (Man-made behave) on canvas $100 \mathrm{~cm}$ length $x 100 \mathrm{~cm}$ width painted by Armen Titof (Collection of Dinas Kebudayaan Provinsi Riau)

The painting entitled "Ulah Tangan Manusia” (Man-madebehave) (Figure 16) constructs the Malay-river and the dark side of civilisation through three main 
images: the human hand, the deteriorated river, and the quote of the Quran verse (Surah Al Baqarah: 11), as the principle signs in this painting. This painting shows the human hand causing damage to the river or environment in the Malay land, which is not following what is supposed to be followed, as it is mentioned in the Quran "Makenot mischief on theearth.' Theriver, forest, and land, which function as the source of Malay life, are damaged by human greed. His painting reminds humans to "keep the environment safe for a better life."

The painting entitled "Tercemar Limbah Beracun (Polluted by Poisonous Waste) (Figure 17) constructs the dark side of civilisation through the elements of a river, dead fish, birds, and factories that release smoke into the air and spew waste into the river. There is also a fisherman squatting on the banks of the river. This painting depicts the pollution that occurs in the river due to the toxic waste that flows in to the river.

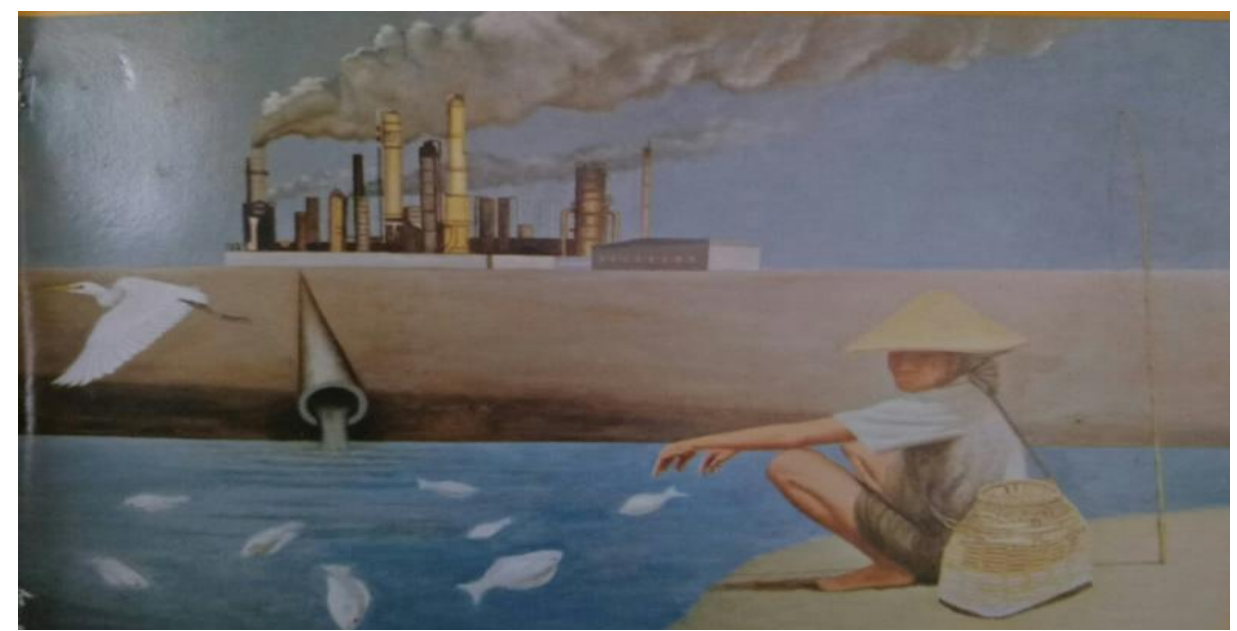

Figure 17: Oil Painting “Tercemar Limbah Beracun (Polluted by Poisonous Waste) on Canvas $100 \mathrm{~cm}$ Length x $140 \mathrm{~cm}$ Width by Rusli (Collection of Dinas Kebudayaan Provinsi Riau)

The illustration of the dead fish further affirms that the damage is caused by the pollution of the river. Furthermore, the deteriorated river has a bad impact on fishermen who depend on the river for their living. The squatting position depicts the local community's helplessness to stop the contamination of the river. As a result, fishermen can no longer catch fish because the fish in the river are dead. The iconic image is intentionally displayed with the existence of a company owned by non-local persons or en trepreneurs that have a huge amount of capital. They are increasingly gaining wealth by exploiting the forests and rivers in the Malay land. In contrast, the Malay fishermen on the banks of the river suffer from 
being unable to catch the fish anymore. This is the picture of the fate of the Malays on the banks of the river that are now threatened by capitalist domination that continues to exploit the natural resources for financial gain.

The painting entitled "Leighton I" (Figure 18) constructs the dark side of civilisation through the elements of the Siak River, Leighton I Bridge, children fishing, and the poor houses near the river banks. Presently, the Siak River and Leighton I Bridge are two iconic places of Pekanbaru city. This painting tries to depict the life of the Malays on the banks of theSiak River. The Malay images in the painting are somehow being presented as livelihood activities, e.g., fishing and other activities, which are strongly related to Siak River. Leighton I Bridge over the Siak River gives the image that civilisation keeps running in the Malay land. This bridge is somehow presented as the symbol of advancement or civilisation of a region, which also reflects and connects between the past and present day of Pekanbaru.

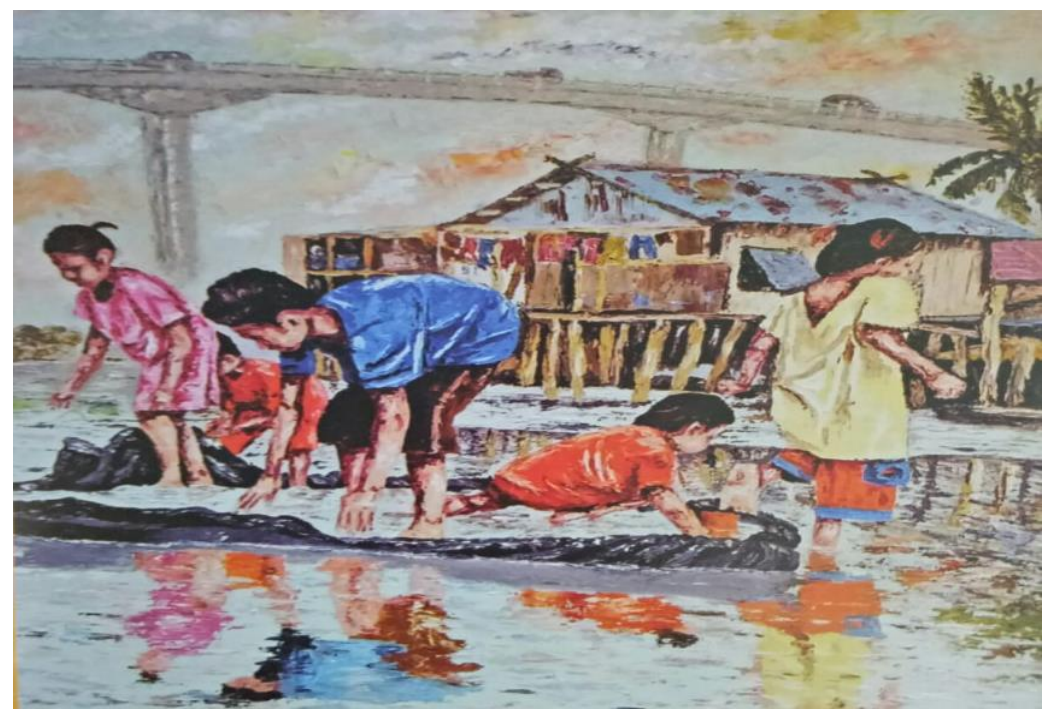

Figure 18: Oil Painting "Leighton $I^{\prime \prime}$ on Canvas $100 \mathrm{~cm}$ Length $x 100 \mathrm{~cm}$ Width painted by Yulianto (Collection of Dinas Kebudayaan Provinsi Riau)

However, under the lean bridge of Leighton I, somehow, this painting is also sending a message that there are still a lot of unlucky people staying under the bridge. The principle signs in the painting capture the current situation, which reveals that not all people in Riau province can taste the sense of happiness through modernisation. The house image belongs to fishermen who earn their living from the river and also has become the principal sign of the existence of 
poverty in the Malay land. It also reveals that civilisation in the Malay land does not always result in a better life for all people. Some people remain marginalised from the development and keep living by Siak River, while the children who are trying to catch a fish or playing with the water symbolise it perfectly.

The painting entitled "Suara Pribumi" (The Voice of the Indigenous People) (Figure 19) constructs the dark side of civilisation through the elements, the use of dark colour, and various sizes of unhappy fish. These fish are trying to reach the water's surface as if they intended to convey a message to the world "we are not happy here". In line with the title, "Suara Pribumi" (The Voice of Indigenous People), this painting portrays the voice or dreams of the Malay s due to the marginal condition they encounter. Sociologically, the voice of the indigenous Malays is indeed marginalised in the modern civilisation in this present day. The Malay people feel unhappy in their land, a land that is supposed to be giving them prosperity. Indeed, now they are marching to seek attention on thesurface. It seems that they feel that they arelosers in their homeland. Therefore, the principle signs of this picture try to depict fish marching to the surface.

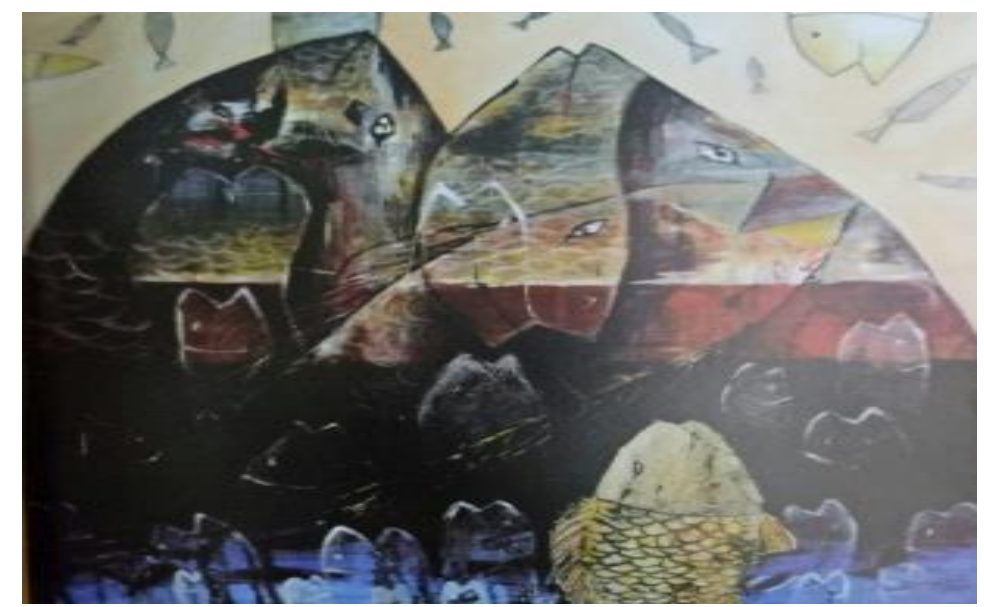

Figure 19: Acrylic painting "Suara Pribumi" (The Voice of the Indigenous People) on canvas $120 \mathrm{~cm}$ length $x 100 \mathrm{~cm}$ width painted by Rahmad Dani (Collection of Dinas Kebudayaan Provinsi Riau)

The Malay voice featured in this painting contains the resistance to gain their rights as the privileged people who own the land. Therefore, they need to show their self to the world. It also sends a message that they can compete with non-local people and can also fight the capital owners who continue to exploit their homeland's natural resources. Nevertheless, this painting also tries to say "they are just small fish if they decide to stay at the bottom." 
The painting entitled "Pasar Tepian Sungai Siak" (A Market by the Siak River) (Figure 20) constructs the dark side of civilisation through the elements of the poor image of Pasar Bawah market, which is situated on a bank of the Siak River, Pekanbaru. Historically, the market is essentially at the beginning of Pekanbaru city. The principle image of the painting depicts two parts of the building situated side by side. On one side, an old building stands, which is made of board and the roof is rusty, owned by a local Malay. In contrast, on the other side, a concrete shophouse building stands owned by migrant people. The old building represents the old life that is still present, but it is more and more threatened by the development that focuses on economic development rather than social development. This painting shows the condition of economic rivalry in the civilisation of Pekanbaru city. The rivalry threatens social interaction and the behaviour is becoming more in dividual and selfish. The presence of shop houses is a symbol of economic power that is concerned more with money than social relations. Nevertheless, this painting tries to send a message that the local Malays were defeated in their homeland".

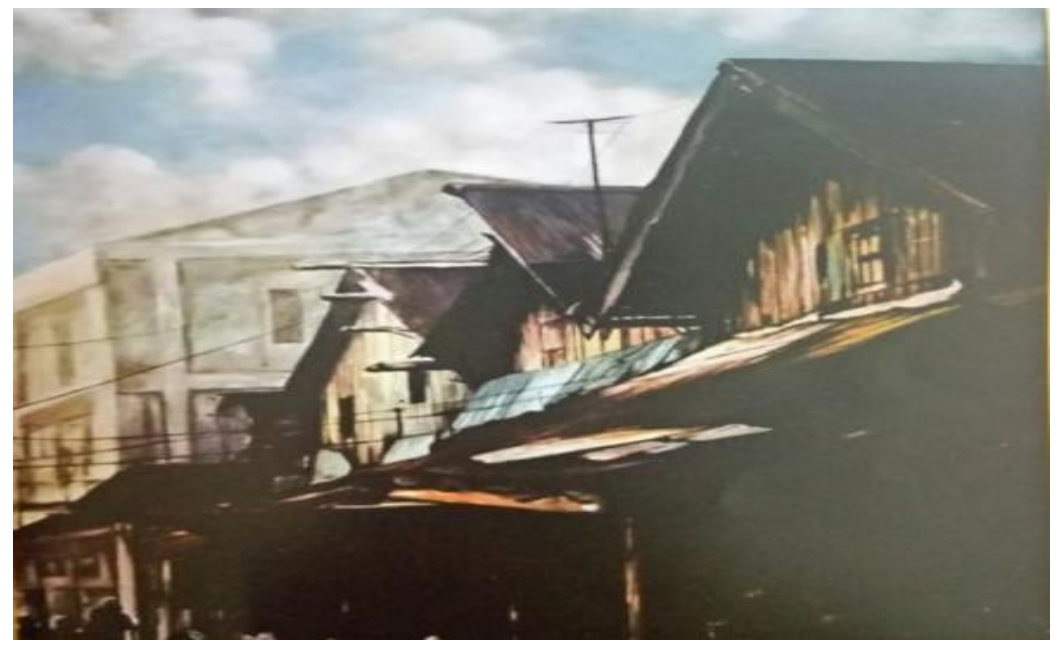

Figure 20: Acrylic painting "Pasar Tepian Sungai Siak" (A Market by the Siak River) on canvas $120 \mathrm{~cm}$ length $\times 110 \mathrm{~cm}$ width painted by Dasril (Collection of Dinas Kebudayaan Provinsi Riau)

The painting entitled "Colonisation Path" (Figure 21) constructs the dark side of civilisation in this painting through the elements of the poor old fisherman image, a river, and a Siak bridge. The principle sign here is the old fisherman's face with a bridge background over the Siak river bridge. The face is wrinkled and shows the struggle and suffering over the years. The painting tries to send a 
message through the old fisherman's face "marginalisation by the modern civilisation". As this painting depicts the bridge that becomes the symbol of modern civilisation in Pekanbarujust flies over the fishermen's life. It is likely trying to underline that this poor Malay fisherman does not receive any advantages from modern civilisation.

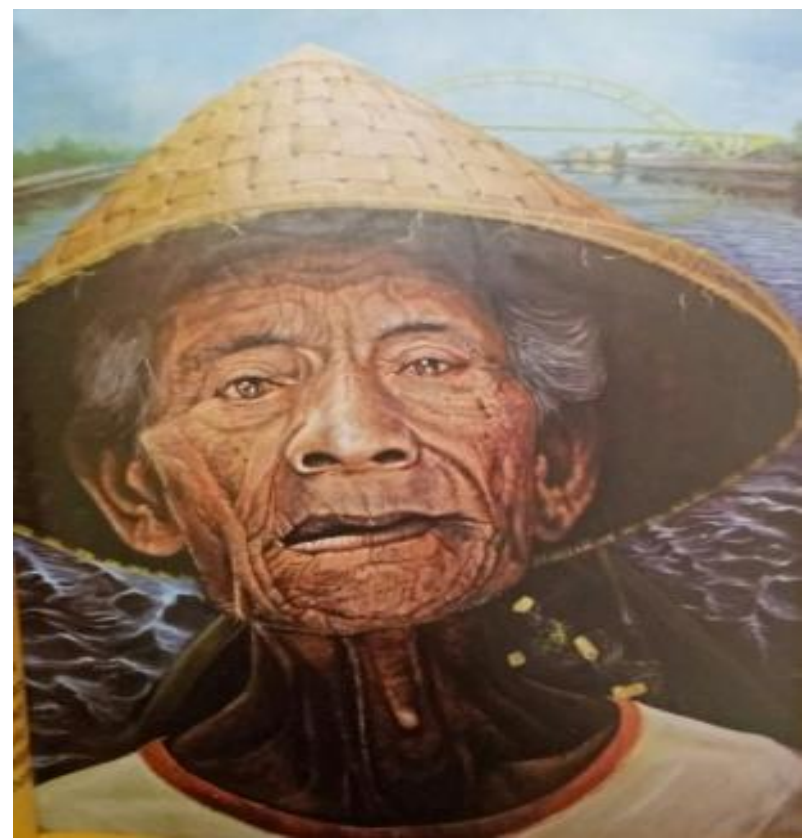

Figure 21: Acrylic painting "Colonisation Path" on canvas $143 \mathrm{~cm}$ length $x 120 \mathrm{~cm}$ width painted by John)

(Collection of Dinas Kebudayaan Provinsi Riau)

\section{Conclusion}

Understanding art knowledge through a semiotic point of view is important for the development of visual art like painting. Bridging art knowledge to society through a painting made by a local artist will provide a strong stance. This paper reveals several principle signs, images, and symbols to seek for a message that might be a constraint for the development of art knowledge in the visual art field in Riau Malay society. Therefore, this study has the opportunity of exploring the 21 paintings using a semiotic approach to explore the existence of ideas and the message beyond. The analysis of these paintings was conducted by observing and interpreting the principal signs, images, and symbols presented within them.

What the present study sees through these 21 paintings is the existence of strong ideas between the Malays, the rivers, and their civilisation. The images, 
symbols or the principle signs that are analysed in these paintings, e.g., water, waves, fish, boats, fishermen, coconut palms, bridges, ports, markets, figures, etc. These images were found as symbolic elements or principle signs that are presented in the paintings. It seems that the Malay civilisation and culture were strongly influenced by their rivers. However, the messages interpreted in the paintings somehow try to tell us that beyond the beauty of the Malay cultural identity and their civilisation, there is also a problematic situation among them, e.g., marginalisation, nature destruction, corruption, and rivalry. The paintings are also somehow sending a message that the Malay spirit of the river and Islamic iden tities make them motivated to confront the various challenges they encounter in their life.

However, some pictures seem to convey critical messages on the current situation of how Malays are responsible for natural destruction at an unprecedented rate, as well as threatening the survival of endemic species and their future. Some of these pictures display the destruction of biodiversity and the ecosystem. Moreover, some of the pictures also frame the environmental degradation through the images and the principle signs concerning the depletion of resources, e.g., air, water (river) and soil; the destruction of ecosystems; destruction of habitats; the extinction of wildlife; and pollution. It seems that some of the paintings may be a warning as well as a reminder for the Malays.

\section{Acknow ledgements}

This research was funded by the Institute of Research and Community Service (LPPM) Universitas Lancang Lancang Kuning, Pekanbaru in 2018. It was also supported by Dinas Kebudayaan Provinsi Riau for using paintings as the objects of this research. Therefore, the authors would like to express their sincere gratitude. Any opinions, findings, and conclusions or recommendations expressed in this material are those of the authors and do not necessarily reflect the views of the respected institution.

\section{References}

Al Azhar. (1997). Malayness in Riau: The study and revitalization of identity. Bijdragen tot de Taal-, Land-en Volkenkunde, 153(4), 764-773.

Augustyn, P. S. (2001). The semiotics of fate, death, and the soul in Germanic culture: The Christianization of Old Saxon. New York: Peter Lang Publishing. 
Bal, M., \& Bryson, N. (1991). Semiotics and art history. The art bulletin, 73(2), 174208.

Barnard, T. P. (Ed.). (2004). Contesting Malayness: Malay identity across boundaries. Singapore: NUS Press.

Barnard, T. P., \& Maier, H. M. (2004). Melayu, Malay, Maleis: Journeys through the identity of a collection. In T. P. Barnard (Ed.), Contesting Malayness: Malay identity across boundaries (pp. ix-xiii). Singapore: Singapore University Press.

Becker, H. S. (1989). Art as collective action. In A. W. Foster \& J. R. Blau (Eds.), Art and society: Readings in the sociology of the arts (pp. 41-54). Albany: State University of New York Press.

Bourdieu, P. (1968). Outline of a sociological theory of art perception. International Social Science Journal, 20(4), 589-612.

Brejcha, J., \& Marcus, A. (2013). Semiotics of interaction: Towards a UI Alphabet. In International Conference on Human-Computer Interaction (pp. 13-21). Berlin: Springer.

Chandler, D., (2017). Semiotics: The basics. Abingdon: Routledge.

Charman, H., \& Ross, M. (2006). Contemporary art and the role of interpretation: Reflections from Tate Modern's summer institute for teachers. International Journal of Art $\mathcal{E}$ Design Education, 25(1), 28-41.

Dahlan, A. (2015). Sejarah Melayu. Jakarta: Kepustakaan Populer Gramedia.

Drew, G. (2012). Ecological change and the sociocultural consequences of the Ganges River's decline. In B. R. Johnston, L. Hiwasaki, I. J. Klaver, A. Ramos-Castillo, \& V. Strang (Eds.), Water, cultural diversity, and global environmental change (pp. 203-218). New York: UNESCO.

Goodman, N. (1968). Languages of art: An approach to a theory of symbols. Indianapolis: Hackett Publishing.

Gracia, J. J. (2012). Painting Borges: Philosophy interpreting art interpreting literature. Albany: State University of New York Press.

Hamidy, U. U. (2011). Jagad Melayu dalam lintasan budaya di Riau. Pekanbaru: Bilik Kreatif.

Helguera, P. (2011). Socially engaged art. New York: Jorge Pinto Books.

Hiwasaki, L. (2012). 'Water for life'... Water for whose life? Water, cultural diversity sustainable development in the United Nations. In B. R. Johnston, L. Hiwasaki, I. J. Klaver, A. Ramos-Castillo, \& V. Strang (Eds.), Water, cultural diversity, and global environmental change (pp. 509-531). New York: UNESCO.

Hodge, B. (2014). Social semiotics. In T. Miller (Ed.), The Routledge companion to global popular culture (pp. 58-66). New York: Routledge. 
Kelly, O. (1985) Community, art and the state: Storming the Citadels. London: Comedia.

Klaver, I. (2012). Placing water and culture. In B. R. Johnston, L. Hiwasaki, I. J. Klaver, A. Ramos-Castillo, \& V. Strang (Eds.), Water, cultural diversity, and global environmental change (pp. 9-29). New York: UNESCO.

Lun, Y. (2012). Water knowledge, use, and governance: Tibetan participatory development along the Mekong (Langcangjiang) River, in Yunnan, China. In B. R. Johnston, L. Hiwasaki, I. J. Klaver, A. Ramos-Castillo, \& V. Strang (Eds.), Water, cultural diversity, and global environmental change (pp. 185201). New York: UNESCO.

Norris, S. (2013). Multimodal (inter) action analysis. In P. Albers, T. Holbrook, \& A. S. Flint (Eds.), New methods of literacy research (pp. 86-100). New York: Routledge.

Paul, D., (1981). In the in terests of civilization: Marxist views of race and culture in the nineteenth century. Journal of the History of Ideas, 42(1), 115-138.

Schapiro, M., (1937). Nature of abstract art (pp. 185-86). Marx ist Quarterly, 1(1), 7798.

Sonesson, G. (1994). Pictorial semiotics, gestalt theory, and the ecology of perception. Semiotica-La Haye Then Berlin-, 99, 319-399.

Thornton, T. (2012). Watersheds and marinescapes: Understanding and maintaining cultural diversity among Southeast Alaska natives. In B. R. Johnston, L. Hiwasaki, I. J. Klaver, A. Ramos-Castillo, \& V. Strang (Eds.), Water, cultural diversity, and global environmental change (pp. 123-136). New York: UNESCO.

Unsworth, L. (Ed.). (2008). Multimodal semiotics: Functional analysis in contexts of education. London: Bloomsbury Publishing.

van Leeuwen, T. (2001). Semiotics and iconography. In T. van Leeuwen \& C. Jewitt (Eds.), The handbook of visual analysis (pp. 92-118). London: SAGE Publications.

Zulkeflie Hj. Ayob, \& Zainuddin Md. Nor. (2012, 1-12 December). Kajian empirikal sumber inspirasi lanskap Melayu dalam rupa bentuk kostum tradisional, motif dan ikatan kain. Paper presented at the $9^{\text {th }}$ Regional Symposium of the Malay Archipelago, Seri Iskandar, Malaysia. 